\title{
Adults Mammary Stem Cell in Cow's Milk: New Perspectives and Future Challenge
}

\section{Baratta $\mathbf{M}^{*}$}

\author{
Department of Veterinary Science, University of Turin, Italy
}

${ }^{*}$ Corresponding author: Baratta M, Department of Veterinary Science, University of Turin (IT), Italy, E-mail: mario.baratta@unito.it

Citation: Baratta M (2013) Adults Mammary Stem Cell in Cow's Milk: New Perspectives and Future Challenge. J Vet Sci Anim Husb 1(2): e202. doi: 10.15744/2348-9790.1.e202

Received Date: September 30, 2013 Accepted Date: October 04, 2013 Published Date: October 07, 2013

The discovery of the presence of stem cells and precursors with high regenerative potential in the mammary gland, hypothetically maintained throughout the course of the productive life of the dairy cow sheds an interesting perspective in the research which is interested to clarify all physiological clues and possible solutions to increase or maintain longer the potential production of dairy cows during life span of lactation. In 2006, Connie Eaves' lab in Vancouver (Stingl et ., 2006) [1] and Jane Visvader in Victoria (AU) (Schackleton et al., 2006) [2] have published the discovery of single mammary stem cells can repopulate the alveolar functional unit in mouse mammary gland. Later, bovine adult mammary stem cells have been functionally identified to regenerate alveoli that secrete milk $[3,4]$. Very recently it was described in human the presence of breast stem cells in milk and this finding is now paving the way for investigation of the functions of these cells in the breastfed infant and the use of breast milk as a tool to understand the normal biology of the breast and its pathologies [5]. In dairy science these findings may be of great interest both from a scientific point of view and for possible future impacts on the economic chain of production of milk.

The dairy cow is characterized by a typical milk-production curve that rises shortly after parturition, is maintained for a variable period of time and then decreases for most of the milking period. When the lactating cow is pregnant, lactation is terminated by at least 40 days of the transition period, during which the animal is preparing for successive lactation and does not produce milk. Mammary stem cells should provide for net growth, renewal and turnover of mammary epithelial cells, and are therefore potential targets for strategies to increase production efficiency. Appropriate regulation of mammary stem cells can potentially benefit milk yield, persistency, dry period management and repair of mammary tissue damaged by mastitis [6]. Cows that tend to maintain their peak yield for longer than average are referred to as persistent. Increased persistence is associated with increased milk production and economic profit. Persistent cows are also healthier since they are exposed to less stress caused by consecutive pregnancies and deliveries and lower metabolic, fertility and health risks. Thus, an attractive approach to improving the ef- ficiency of milk production involves maintaining the initially high level of milk secretion over a longer period of time. The reduction in the number of "dry periods" also contributes to the efficiency of lactation. The milk-production industry has a significant impact on most national economies. In Europe more than 91 billions liters of milk are produced annually with costs ranged according to the national countries from 30 to 90 euro (IFCN Dairy report 2011, www.ifcndairy.org) The sharp rise in the price of grain, as nutrients but now also for fuel production, endangers the milk industry worldwide. Since global overproduction has been eliminated by increasing milk consumption in the Orient, the ability to meet consumer demand maybe be again requested. Secondly, the presence of mammary stem cells in the milk open the possibility to use a non-invasive system for the recovery of primitive cells from the mammary gland that could be a simple and rapid method which can easily provide the necessary amount of cells to be monitored on the functional status of the bovine mammary gland. The exciting possibility that stem cell expansion can influence milk production is currently under investigation. Additional studies are necessary to more fully characterize the bovine mammary stem niche, the regulation, turnover and differentiation of epithelial mammary cells during the mammary gland development and their role in milk. But the complete development of markers for stem cells and progenitor cells will facilitate evaluation of the potential impacts of traditional management strategies and strategies designed to impact mammary stem cell and progenitor cell function. The challenge is to comprehend the interaction among these components that allows the long-term maintenance of mammary stem cells activity' and develop effective strategies to impact this activity.

\section{References}

1. Martignani E, Eirew P, Accornero P, Eaves CJ, Baratta M (2010) Human milk protein production in xenografts of genetically engineered bovine mammary epithelial stem cells. PLoS One 5: e13372.

2. Rauner G, Barash I (2012) Cell hierarchy and lineage commitment in the bovine mammary gland. PLoS One 7: e30113. 
3. Hassiotou F, Beltran A, Chetwynd E, Stuebe AM, Twigger AJ, et al. (2012) Breastmilk is a novel source of stem cells with multilineage differentiation potential. Stem Cells 30:2164-74.

4. Capuco AV, Choudhary RK, Daniels KM, Li RW, Evock-Clover CM (2012) Bovine mammary stem cells: cell biology meets production agriculture. Animal. 6:382-93.
5. Shackleton M, Vaillant F, Simpson KJ, Stingl J, Smyth GK, et al. (2006) Generation of a functional mammary gland from a single stem cell. Nature 439: 84-88.

6. Stingl J, Eirew P, Ricketson I, Shackleton M, Vaillant F, et al. (2006) Purification and unique properties of mammary epithelial stem cells. Nature 439: 993-7. 